\title{
The Interface of Documentary and Fiction: The Amber Film Workshop and Regional Documentary Practice
}

\author{
Jack Newsinger
}

\begin{abstract}
Really I don't think there's been any contribution by Britain to documentary in the last ten years of any new sort. I see the next chapter being making films really locally... the local film people making films to state their case politically or otherwise, to express themselves. (John Grierson, quoted in Sussex 1972: 26, 30)
\end{abstract}

Regional workshop film-makers of the 1970s and 1980s appropriated the theory and aesthetics of British documentary cinema in specific ways in their attempt to construct a politically and culturally progressive cinema practice, representing both a change and a continuation in the values and practices of the British documentary tradition. What determined these changes and how the documentary tradition, founded in the 1930s by John Grierson, was taken up and deployed will form the basis of the argument of this paper. This will be explored through an analysis of the films and film-making practices of the Amber Film Workshop, the first, most significant and longest surviving regional film workshop (up to the point where Theresa Fitzgerald argues that they 'established a model and a working practice to which all other... workshops [were] being obliged to conform' (1988: 169)).

Amber was formed by a group of students who met while studying film at the Regent Street Polytechnic in London in 1967. The original members were Murray Martin, Graham Denham, Peter Roberts and Lorna Powell, all university graduates from working-class backgrounds, and Sirkka Liisa Konttinen from Finland. The group relocated to Newcastle in 1969 out of a desire to work outside the structures of the London-based industry in a region that had a strong sense of its own identity (Amber 2005: 1). Amber's stated purpose was to 


\section{Jack Newsinger}

document traditional regional working-class communities in the North East, a culture that was in decline as traditional manufacturing jobs disappeared and were replaced by low-paid, casualised work in the service sector.

From the outset, Amber fully incorporated an egalitarian structure and cross-grade working practice into their formation, each member of the group taking an equal wage. Accordingly, all its films are ascribed collective authorship and made through a process of collaboration. In 1971 Amber rented premises on the Newcastle Quayside, buying the buildings in the late 1970s when the Quayside was threatened with demolition (and later successfully leading a campaign for its preservation, which would be the subject of their 1979 film Quayside). The buildings were converted into a film workshop, a cinema and the Side photographic gallery. As well as working in film Amber was active in photography and the Live Theatre movement, the separate areas informing one another. This integration of activity attracted revenue funding for photography from Northern Arts and film exhibition funding from the BFI, funds which contributed to the film production of the period along with money earned from freelance work which was pooled back into production so as to maintain a degree of financial independence.

Their work can be divided into three overlapping phases or strands. The first is the series of short documentaries made in the 1970s recording traditional industrial processes, a type of film that Darren Newbury has called 'salvage documentary' (2002: 114). The second phase begins in 1983 with Byker and sees the group experimenting with documentary and fictional or narrative practices. The third strand is their more explicit campaigning work, particularly that centred on the Miners' Strike (1984-5). ${ }^{1}$ This article is concerned with the first two strands as representing the development of the documentary tradition in their work. Up to 2007 the group have made some 40 films, almost all of which explore working-class identity in the North East. As Ellin Hare notes: 'All of the films are experiments, and each one has a slightly different way of making that interface between documentary and fiction' (Young 2001: 72).

Amber's body of work is unique in British cinema through its engagement with specific local communities and working-class identity in the North East over nearly four decades. Yet where they do appear in British cinema history it is normally in relation to the politics of the Workshop Movement. While their key role in the movement certainly should not be understated, ${ }^{2}$ attention to this has arguably been at the expense of a consideration of their contribution to the theory and 


\section{The Interface of Documentary and Fiction}

practice of documentary film-making and the representation of the Northern working class in British cinema. Part of the argument in this article is that the existence of regional documentary demands the extension of the history of British documentary cinema beyond the 1960s and Free Cinema. ${ }^{3}$

The argument will proceed first by contextualising Amber's development within the economic and social conditions of the 1970s and 1980s, particularly within the North of England. Then it will move on to Amber itself and the development of documentary practice within its work, first considering the 'salvage documentaries' and then moving on to its experiments with the documentary form.

\section{Contexts}

If the documentary movement can be defined by the 'social democratic consensus' - a belief in the state as a benevolent force for the regulation of capitalism combined with an overriding collectivist notion of social relationships within the public sphere - then the 1960s saw increasingly the growth of cultural practices which were oppositional to the state.

For Murray Martin the degree of independence from the agendas of the funding bodies which characterised the regional film production sector in the 1970s and 1980s marks a key difference between Amber's approach and that of the 1930s documentarists:

The difference between that constituency and us was that in many ways the 1930s filmmakers worked for the state, were employed by it and censored by it. Hence there are no images of unemployment from the 1930 s or at least very few ... We came from an artistic background but one with a political dimension. It is a different tangent and a much more independent one. (Beynon 2001: 162-3)

This 'different tangent' involved the re-articulation of the documentary impulse to record and communicate ideas about the working class within an overtly ideological model which stressed class conflict and contradiction.

This can be explained by examining the social and political context from which Amber emerged and, in particular, the changes in the articulation of class and region. While, as Darren Newbury notes, 'in the early 1970s, working-class institutions such as the trade unions represented a powerful political force, and working-class identity could be seen in a positive light' (2002: 114), this changed sharply during the late 1970s, culminating with the election of Margaret Thatcher's Conservative government in 1979. Historian Richard Weight describes a significant redistribution of wealth under Thatcher which manifested 


\section{Jack Newsinger}

itself and was experienced in regional terms as an "orgy of prosperity in Southern England [which] created a stark "north-south" divide'. Thatcher set about dismantling regional spatial subsidies as part of her more generalised attack on the welfare state and by 1986 unemployment in the North of England was sixty per cent higher than in the South (2002: 591-2). For Robert Colls this was part of a change in the character of the North in British social and cultural life, moving the region in national cultural geography from a place in need of assistance to a zone far out on the margins as privilege, wealth and national identity became concentrated in the South East (2002: 332-3). As Dave Russell notes, the North-South divide became a staple of political discourse:

While it is difficult to sustain any reading of 'North-South' relationships over the long term in truly colonial terms, it is not surprising that some politically engaged northerners began to view themselves as living under precisely such an arrangement from the 1980s. (2004: 29)

This resulted in the consolidation of one image of the North as backward, defined by failed industry and unemployment, and peopled by brutish union men and petty criminals. As Raphael Samuel describes it:

The very qualities which had recommended it to the 'new wave' writers and filmmakers now served as talismans of narrowness. The rich associational life, such as that of the workingmen's club, was seen not as supportive but as excluding, a way in which the natives could keep newcomers and strangers at bay... The solidarities of the workplace were reconceptualised as a species of male bonding, a licence for the subjugation of women; while smokestack industries which had been the pride of the North now appeared, retrospectively, as ecological nightmares. In another set of dialectical inversions, the modernisations of the 1960s were stigmatised as planning disasters, imprisoning the local population in no-go estates and tower blocks. (Quoted in Russell 2004: 29)

These social and political tensions would receive their fullest expression in the 1984-5 Miners' Strike which signalled 'a permanent shift in the balance of power in British politics' (Newbury 2002: 114). A bitter and violent struggle, it marked the most significant stage of Thatcher's strategic assault on traditional working-class institutions in Britain, of which the National Union of Mineworkers (NUM) was one the largest, best organised and most militant. ${ }^{4}$ Its effects were particularly harshly felt in the traditionally Labour-supporting industrial heartlands of the North and the Midlands. 


\section{The Interface of Documentary and Fiction}

In Newcastle, de-industrialisation had begun towards the beginning of the twentieth century and accelerated from the late 1960s (Vall 2001: $47-70)$. This coincided with a large programme of city redevelopment under the Labour administration from 1958, embodied in the 'Burns Plan'. This included infrastructure development and a comprehensive clearance and redevelopment of inner-city housing areas so as to adjust the city's economy from manufacturing to one based on property development, leisure and consumerism. Newcastle had relatively few slum areas; however, for Wilfred Burns, Chief Planning Officer from 1958, housing clearance had other advantages:

One result of slum clearance is that a considerable movement of people takes place over long distances, with devastating effect on the social groupings built up over the years. But, one might argue this is a good thing when we are dealing with people who have no initiative or civic pride. The task, surely, is to break up such groupings even though the people seem to be satisfied with their miserable environment and seem to enjoy an extrovert social life in their own locality. (Quoted in Byrne 2001: 346-7)

City planning in Newcastle through to the 1980s, as David Byrne notes, was both a technical and sociological project, 'the assertion of the form of the future' (ibid.: 344-9). That this contained an overt hostility towards the traditional identity of the urban working class in the city is abundantly clear.

Social, economic and cultural divisions were, therefore, realised nationally in the expression of the North-South divide, but also internally in the North in a dichotomy between the politics of tradition and 'modernisation'. However, Amber's early work was guided less by a reasoned response to cinematic traditions or class politics and more by a set of feelings incorporating, variously, a non-sectarian leftist critique of established institutions and the mainstream media, an attachment to and interest in traditional forms of regional working-class identity and a desire for artistic expression. Martin, for example, recalling the group's early motivations, states that 'we were conscious that we were creative people who felt that we were making imagery about a particular culture'. He continues: 'I felt there was a job to be done of recording working-class culture before it disappeared, and celebrating it' (Newbury 2002: 117, 119). The desire creatively to document and celebrate the working class in Newcastle clearly echoes the aesthetic ambitions which motivated Grierson. Take this statement, for example:

When we come to documentary we come to the actual world, to the world of streets, of the tenements and the factories, the living people and 


\section{Jack Newsinger}

observation of living people, but I charge you to remember that the task of reality before you is not one of reproduction but of interpretation. We have to give creative shape to it, we have to be profound about it before our documentary art is as good or better than the art of the studio... It is only good if its interpretation is a real interpretation, that is to say one which lights up the fact, which brings it alive, which indicates precisely and deeply our human relation to it. (Grierson 1998: 76-7)

However, when placed in the context of the late 1970s and early 1980s, the expression of a traditional regional working-class identity could take on an oppositional cultural politics. Put another way, while Grierson and the documentary movement constructed the representation of the working class within a discourse of public service to the state, for Martin and Amber the function of documentary is constructed within a discourse of service to the Northern working class which stands in opposition to the state:

We constantly get into this battle about the representation of the working class... I often say Prince Charles can have a cloth cap, but the working classes can't - the upper classes understand their traditions, and defend them. The power structure has Black Rod knocking on Parliament's door, to see the MPs through. And all the MPs go and kneel at the Queen's feet and say, 'We swear allegiance to you above even our party', and then join the Privy Council-all those traditions are fine, but when the working class have a history, like mining, it is erased at a frightening rate. (Young 2001: 68)

Amber's work explores working-class identity in the North East during a period of intense transformation of the identity of the region, with old connotations persisting as well as being contested and supplanted. This is central to the way Amber's work can be understood. Its films chart the response to industrial decline in the region while at the same time dramatising a confrontation between traditional forms of working-class identity and 'modernisation'. This begins with the 'salvage documentaries' of the 1970s, which take up the thematic concerns and aesthetic practices of the documentary movement. From the early 1980s a change is discernible in Amber's work, which moves away from straightforward documentary and into experimentation with the documentary form - the 'interface between documentary and fiction'. Concurrent with these developments in scale and ambition, the group developed a coherent operational and ideological model for a regional film workshop with close links to the communities which formed their subjects and a long-term commitment to the expression of the identity of the region. This was accompanied by 


\section{The Interface of Documentary and Fiction}

the development of 'socially embedded' film-making practices which attempted to overcome some of the perceived limitations inherent in the documentary tradition, in particular the 'top-down' approach to the documentation of working-class culture for which Grierson and his colleagues have been so thoroughly indicted. ${ }^{5}$ As a result, Amber's later work moves away from a monolithic construction of regional workingclass identity based on industrial labour and masculinity and towards more complex representations based on difference, in terms of gender, generation and the experience of marginalisation, as the traditional markers of regional identity became unstable. What follows will trace this development in regional documentary practice.

\section{'Salvage documentary'}

With limited funds for film production, Amber's early work was intermittent, combining photography and film. Martin describes the production of their first film in the early 1970s:

I remember Sirkka, myself and Pete going out one sunny morning, we got in the car and we drove. We went down to Wallsend where they were building one of these giant tankers, and we stood there almost in awe of this and said 'let's make a film about this', you know, to celebrate working people. We wanted to make a film which reflected their pride and achievement in making this object. (Newbury 2002: 118)

The film in question, Launch (1973), was followed by Bowes Line (1975, about a coal wagon railway), Last Shift (1976, about a brick works) and Glass Works (1977). These documentaries can be aligned very closely with the ideas about the social function of the cinema and the aesthetic ambitions and procedures of the 1930s documentary movement. At the most basic level, the idea of the function of documentary as a means of recording and communicating ideas about working-class culture corresponds to the principles of cinematic practice at the heart of the documentary movement. The concern with the appropriate visual imagery with which to communicate these ideas - the 'creative interpretation of reality', in Grierson's oft-quoted phrase-places the films squarely within the boundaries of the documentary tradition. Martin's repeatedly expressed enthusiasm for the iconic markers of working-class identity, the achievements of working-class culture in the region, echo Grierson's own enthusiasm for the 'hero worker', the 'ardour and bravery of common labour' (quoted in Colls and Dodd 1985: 24). 


\section{Jack Newsinger}

All the films focus on work, with Last Shift and Glass Works looking to pre-mechanised industrial processes. Within this there is an emphasis on the detail of the craft skills of the workers and on their working conditions. With the exception of Launch they do not look outside the immediate context of production or attempt to place the workers and products as part of a wider social system. In this way the subjects function as roles and are fully integrated with the processes which the films depict. Taken together they construct regional workingclass identity based on the iconic markers of industrialism: physicality, craftsmanship, collectivity and masculinity.

Stylistically the films are unobtrusive and distanced, free from commentary or characterisation. This deliberate refusal to editorialise leaves their meanings relatively open, highlighting the aesthetic qualities of the images. They are constructed through montage techniques which emphasise composition, rhythm and movement, with the processes functioning as spectacle and rendered abstract. In this way they can be viewed as celebrations or romanticisations of regional identity based on maleness and industry and which is mediated through an 'art' aesthetic. However, if they continue in the aesthetic tradition of the documentary movement-the male worker as hero-the films also reveal a politics at odds with the documentary movement's social-democratic tendencies. This can be explored through a more detailed analysis of Launch.

Launch was shot in the early 1970s when Amber was given access to a shipyard directly backing onto a street in Wallsend. The film shows the construction of the World Union oil tanker and its eventual departure from the yard. It is a series of short (the film was shot using a windup Bolex $16 \mathrm{~mm}$ camera with a maximum shot duration of twenty seconds) wide-angle composition shots animated by the movement of heavy machinery and men at work, and finishing with Princess Anne and local dignitaries christening the launch and an extended sequence of the view from between the terraced houses as the completed ship moves out towards the sea.

The film is defined by industry: heavy machinery, steam and noise. We see the ship constructed, welded and painted, and are shown the scale of the endeavour. The focus is on processes, and frequently the workers are not fully in shot or are out of focus, the industrial site becoming the subject of the film. There is a concern with the sociality of the workplace, shown in several close-ups of men smoking and laughing, but no individual characterisation.

The shots are carefully composed and mostly static, with a considerable emphasis on scale, light/shadow and movement. This 


\section{The Interface of Documentary and Fiction}

sense of the aesthetic qualities of the industrial is further emphasised by editing which undercuts a narrative dynamic. While there is attention to the detail of the work, there is little explanation or attempt to communicate information about what is happening and why. In this way, the processes are removed from the context of industrial labour relations and rendered as spectacle, finishing with the shot of the ship moving out to sea which completes the film. Like the other Amber films in this series, Launch integrates industrial labour and workingclass identity.

The final part of the film shows women and children emerging from the tightly lined terraced houses to witness the christening of the ship. Again the camera remains distant, observing interactions without characterisation. The community line a wall to watch the launch and the camera assumes their point of view, observing through a glass barrier the dignitaries approaching the ship. Ultimately the workers and their families are excluded from the ceremony. In this final sequence, then, there is a concern to represent class divisions which undercut the aesthetic practices of the first part of the film.

This dual concern with visual celebration and social critique can be seen in the other 'salvage documentaries', all of which look at traditional industrial processes on the verge of disappearance. That the dramatisation of this dichotomy is part of a political response to de-industrialisation is made explicit by Graeme Rigby, another Amber member:

People might dismiss that as romanticising the landscape of industrial culture. It's probably more important to realise that this is actually what's been taken away from people's lives. This is a whole dimension within which they found identity, an identity in which they could feel proud. You take that away and people's lives are diminished and that should be acknowledged. (Interview with the author, 2007; all subsequent quotations from Rigby are taken from this source)

Many of the thematic concerns and aesthetic practices present in Amber's documentaries of the 1970s are continued in its subsequent work: the representation and celebration of working-class culture, a visual interest in the industrial landscape of the North East as central to regional identity and a conception of decline. In particular, the tension between aestheticism and a commitment to the representation of the working class can be seen as a significant continuity between Amber and the documentary tradition. The tension between 'an artists' collective but with a commitment to the working class' has been recognised by Martin as a 'strain within Amber's work in making 


\section{Jack Newsinger}

creative documentaries, which takes you back to the tensions in the 1930s documentary movement' (Beynon 2001: 162). Indeed, the move away from straightforward documentary practices from the 1980s onwards can be seen in large measure as the working through of this tension.

\section{The interface of documentary and fiction}

Several interlinked factors contributed to the transition in Amber's work to film-making practices which experimented with the documentary form. Firstly, Amber's combination of work in theatre, photography and film, all in relation to specific working-class communities in the North East, led to the development of long-term relationships with those communities. This presented the opportunity for more detailed research and documentation over longer periods. At the same time, this combination of activity informed the development of film-making practices which actively involved documentary subjects in the process of constructing meaning, moving into fictional drama and dramatic reconstruction. While this could be seen as a break with the documentary tradition, for Amber it was characterised as an extension of their project of regional documentation which 'gives greater flexibility, makes a depth of exploration possible and opens up a completely different relationship with the communities in which the work is developed' (Amber 2005: 19). For Graeme Rigby, the employment of fictional drama is 'experimenting in the relationship between documentary, community and fiction'. It can, then, be seen as part of an attempt to address the tension between aestheticism and commitment realised at a formal level. For example, Murray Martin argues that 'it was really acting, using working-class people acting and saying what they wanted to. And this not only made [the films] more poetic but also more emotionally accessible' (Beynon 2001: 163). The way in which this in turn informed the thematic concerns present in Amber's work can be seen in Martin's account of the production of High Row:

I worked with a writer called Eric Northey. We were there for about a month, working in the mine. That was part of the romance, we actually went and did a job there as part of the research. What we said as we wrote the script was that the work is dangerous and claustrophobic, because you crawl down the hole basically and the roof falls in all the time, and you can't see underground. But when we showed the script to the men, they said, 'if you think that, you're not a miner'. Their view of themselves was romantic... So we re-wrote the script and made a film which reflected 


\section{The Interface of Documentary and Fiction}

what they thought about themselves... So it's an interesting process, and that process has always been part of reflecting what people think, taking it back to them and having that debate, it's part of the recording of that culture. (Newbury 2002: 119)

Amber's documentary practice sought actively to construct subjective agency within the film-making process and in particular within the documentary form. As Graeme Rigby argues:

The key thing is to do with going into the community and genuinely creating the film out of that engagement rather than imposing your narrative on that. And if you're trying to develop something genuine out of that engagement it is necessarily experimental.

The move into fictional drama is thus articulated as part of Amber's attempt to develop a 'socially embedded' film-making practice. The notion of socially embedded film-making corresponds very closely with the conception of cinema as a social practice which Sylvia Harvey argues defined the independent film sector in Britain during the period, that is cinema as a 'cycle of production and consumption which is concerned with the joint production of meaning by both producer and consumer, and motivated by cultural rather than commercial considerations' (1981: 14). This is put another way by Amber member Pat McCarthy:

It's a grassroots involvement in saying 'the media should belong to you, you should influence it.' Basically, what we're saying to people is that it's an area you should be involved in. It's not something that should be done at you. (Quoted in Fitzgerald 1988: 164)

The 1980s was a period of extraordinary productivity for Amber. Byker was followed by Keeping Time (1983), The Sadler Story (1985), Seacoal (1985), Double Vision (1986), T. Dan Smith (1987), From Marks and Spencers to Marx and Engels (1988), Shields Stories (1988) and In Fading Light (1989). However, from the early 1990s Channel Four, the BFI and the Arts Council withdrew funding from the Workshop sector and shifted priorities toward output made under traditional commissioning and production arrangements. This is reflected in Amber's reduced output of the period: Dream On (1991), The Writing in the Sand (1991), Eden Valley (1994), Letters to Katja (1994), The Scar (1997), Like Father (2001) and Shooting Magpies (2005).

All the above-mentioned films contain elements which can be said to blend documentary with fictional drama or narrative production practices. Within this blend, various thematic, formal and aesthetic 


\section{Jack Newsinger}

mediating techniques are used. For example, Byker, Keeping Time, The Writing in the Sand, Letters to Katja and T. Dan Smith are the most formally experimental, constructed through both 'pure' documentary and reconstruction. With the exception of T. Dan Smith, these films all employ still as well as moving images. Seacoal, In Fading Light, Dream On, The Scar, Like Father and Shooting Magpies are all classically structured feature-length films with central protagonists, dramatic conceits and ultimate narrative resolution. They employ a combination of documentary, reconstruction, improvisation and fictional practices. This blurs the distinction between documentary subject and actor, with a core of regular actors drawn from Live Theatre and the local area appearing in many of Amber's films alongside non-professional actors drawn from local communities.

Thematically there is an overriding emphasis on the experience of de-industrialisation and decline in the region. There is also a continued interest in work as central to working-class identity, with In Fading Light, Dream On, The Scar and Like Father all addressing the decline of traditional industries (in these instances, fishing and coal mining). If regional planners in the 1980s and 1990s sought to erase and disavow the North East's industrial heritage, then for Amber it was still a key symbol of its identity. However, the relationship between work and identity is frequently portrayed as complex and ambivalent, as opposed to integrated and celebratory, with the romanticisation of industrial labour repeatedly undercut by the depiction of harsh conditions, precarious employment and conflict. From the beginning of the 1980s their films foreground a whole series of ambivalent relationships between regional communities, industrial history, social change and internal difference. The pre-eminence of these elements in their later work is explicitly linked by Martin to the defeat of the miners in 1985:

You could celebrate the achievements pre-1984 because they'd gone unrecognised. You could celebrate the fact that people had built a huge ship, however they were treated, or the monumental impact of working in the steelworks. On the one hand it destroyed your health, on the other it gave you a monumental identity.

He continues:

The mining culture had that parameter of brutalization at one end, horrific treatment of people and of each other, and a totally humanist base at the other... It's not just about money, it's about dignity and the belief in the work you do and the status you have... Post Miners' 


\section{The Interface of Documentary and Fiction}

Strike we've been looking even more at the demise of what one would call working-class culture and at the same time being more and more dragged into periphery cultures. (Newbury 2002: 122)

These ideas inform the construction of work and working-class identity in their films throughout the period. At the same time, there is a repeated concern to document sociality and leisure - whether it be pub singing, harness racing or the camaraderie of the workplace-as a rich and vibrant part of working-class life. Often this is contrasted with colder, less inclusive social relationships which define modernisation in the region.

As well as the concern in these films with exploring the challenge to traditional working-class masculinity posed by de-industrialisation, a significant departure from the thematic concerns of the documentary tradition is the focus on women in many of the post-1980 films, and in particular on female experience, gender difference and inequality. In Fading Light, for example, centres on a woman's attempt to join the highly masculine world of the fishing industry and on the hostility which she encounters both from the men on board ship and the women ashore. Similarly Dream On explores the personal lives of three members of a women's darts team and their struggle to overcome domestic violence, abuse and alcoholism.

Many of these themes can be further explored through a more detailed analysis of a specific film. Seacoal is a good example as Amber's first feature-length film. In common with much of Amber's other work, it grew from a photography project to document the seacoaling community at Lynemouth which made their living collecting waste coal washed ashore and selling it to a contractor for recycling. In the early 1980s Amber bought a caravan on the seacoalers' campsite, and this housed the production team on and off for a period of two years while the film was researched and shot. The film is constructed through the actual events at the camp during this period combined with a fictional narrative written by Tom Hadaway (Amber 2005: 13). Seacoal thus mixes documentary footage with fictionalised scenes using actors and reconstructions with actors and local people. ${ }^{6}$ The story concerns Betty (Amber Styles) and her daughter who escape a violent relationship to live in a caravan with Ray (Ray Stubbs), a seacoaler who has returned to the camp after a period working elsewhere. As an outsider, Betty has to adjust to the harsh conditions of life on the beach and the prejudices of the local people towards the seacoalers. The action is framed by the Miners' Strike, which puts pressure on the seacoalers, and the decision by the company which owns the beach to remove them. Ray stockpiles 


\section{Jack Newsinger}

coal in anticipation of a price rise in response to the strike, part of an attempt to buy his own horse and cart so as to escape the exploitative conditions imposed by the company. Ray then loses his coal in a bet and, after an argument with Betty, leaves the camp. The film finishes with Betty choosing to remain on the beach and attempt to earn a living without Ray.

According to Amber's catalogue:

The inspiration for Seacoal undoubtedly came from the staggering visual location in which it is filmed; the industrial landscape of power station and pit framing the blackened beach of Lynemouth where, for generations, local people and travellers have made their living from collecting waste coal washed ashore. (http://www.amber-online.co.uk)

This aesthetics of the beach and its industrial backdrop are repeatedly returned to in the film, portrayed as both severe and beautiful. This dual construction of the landscape is reflected in Ray and Betty's attitude toward their surroundings, with Ray valuing it in terms of freedom and beauty while Betty comments on dirt and deprivation. This landscape is central to the identity of the community, constructing a dualism that is present throughout the film on both an aesthetic and thematic level.

Again, work is central to identity and there is considerable attention placed on visually recording the detail of the work of the seacoalers through a combination of montage and description: sifting and shovelling coal, using horse-drawn carts to transport it, being dependent on the tide. The work is physical and gruelling but not entirely male-dominated. It offers a certain freedom and a harmony with nature which is attractive to Ray and is in this way romanticised. At the same time, the work is placed in the context of the economic exploitation of the seacoalers by the company, Betty describing it as 'slave labour'. This is accompanied by a concern to show and describe the poverty in which the seacoalers live: the lack of running water, the rubbish on the beach, shortage of money, unsuccessful negotiations with benefits agencies, and so on. But the film contrasts this with Betty's life in an abusive marriage on a nearby housing estate and ultimately celebrates the self-determination and community spirit on offer on the beach. However, the narrative resolution of the film leaves even this conclusion uncertain, refusing fully to endorse the seacoalers' way of life.

There is also considerable attention paid to communicating the sociality of the camp: camp fires, music, the pub, gambling and harness racing. In this film, sociality and community are just as 


\section{The Interface of Documentary and Fiction}

significant markers of the community's identity as is labour, and the camaraderie and support offered by local women are central to Betty's decision to stay in the camp. However, the community is also shown to be internally divided, with the seacoalers in competition with each other for resources. This theme is advanced through Ray's rivalry with another seacoaler who eventually wins his coal, leading to his departure. Capitalist production relations are, therefore, integral to the internal life of the community as opposed to an insidious outside force.

The film uses a number of devices to communicate these ambivalences, some of which can be said to be documentary practices and some which are more in keeping with fiction film-making. For example, an extended central sequence shows Betty being accepted by the community, and particularly Rosie (Rosie Laidlaw, a nonprofessional actor) who introduces her to life on the beach. In this sequence documentary footage is interspersed with dialogue between Betty, Rosie and other seacoalers, building a documentation of the community. In this sense, Betty's character functions as a mediating figure who facilitates the expression of experience by the seacoalers themselves. Considerable space is given to Rosie and her family to construct their own identities at the same time as the film records the landscape and the activities taking place within it. This integration of documentary subject with actor forms the basis of much of Amber's film-making practice and was first developed here in Seacoal through an agreement with the actors union, Equity. While the actors' lines were scripted, the agreement stipulated that the non-actors could not be scripted or directed by Amber, so forcing this approach on the group (Amber 2005: 13).

These documentary practices are integrated with fictional narrative devices. For example, early in the film a sub-plot is introduced in which a friend of Ray's, Ronnie (Sammy Johnson), has left the beach, taken a manager's job with the company and moved to a nearby village. This puts his interests at odds with those of his friend and the rest of the community. Ronnie is a symbol of social change and modernisation, embracing business and self-interest at the expense of solidarity and freedom. While this is portrayed with some sympathy, with Ronnie's choice appearing rational in the face of the decline of the seacoalers' way of life, ultimately the film laments the loss of a traditional regional culture in which local people have for generations held common land rights which are now under threat from privatisation. Similarly, the romance between Ray and Betty allows the film to explore gender relationships and identity. The couple are supportive and in conflict in equal measure, arguing about money and work but also working 


\section{Jack Newsinger}

together and sharing childcare. Finally, economic conditions prompt Ray to leave, with Betty becoming empowered by the informal female support network at the camp. Female experience is thus placed at the centre of the film. While the iconic markers of masculinity in relation to labour are present, the gender division between provider and nurturer is destabilised with Betty's decision to work for herself as a seacoaler.

Seacoal can be considered a sophisticated exploration of a thematic dualism between the 'brutalisation' and 'humanism' that Martin describes as central to the identity of the region from the 1980s. This thematic ambivalence, combined with the mixture of documentary and narrative production practices, constructs a complex documentation of a regional community. Finally, the use of the device of the outsider entering the community is repeatedly employed in Amber's films from the early 1980s. While this functions in part as a way of communicating with the audience through exposition, it can also be seen as the symbolic dramatisation of the encounter between the artist and the documentary subject, a formal dramatisation of the tension between aestheticism and commitment that lies at the heart of Amber's encounter with the documentary movement. This point has been put forward by Tobias Hochscherf and James Leggott, who argue:

Amber's films can be read as a kind of commentary on this tradition, in that their films acknowledge, address and even dramatise some of the perceived problems with realist practice. Recurring debates around issues of authenticity, romanticism and, in particular, intervention and adaptation, are woven into the very fabric of the films themselves, thus circumventing, perhaps, some of the alleged pitfalls of this kind of filmmaking. (forthcoming)

This thematic device coexists with the mediating aesthetic practices of the 'salvage documentaries' as a way of addressing the tension between aestheticism and commitment in documentary practice. Amber's experiments with the documentary form in films such as Seacoal thus address, on a thematic, formal and structural level, tensions within the documentary tradition. The frequency with which these themes are interrogated across Amber's filmography is striking and suggests a coherent response both to cinematic traditions and to personal artistry which could imply an auteurist approach even as this is denied by the film-makers themselves.

\section{Conclusion}

It is tempting to see the 'salvage documentaries' of the $1970 \mathrm{~s}$ as simply precursors of Amber's film-making from the 1980s onwards. 


\section{The Interface of Documentary and Fiction}

While in a sense this is the case, it should also be noted that Amber's work developed within certain institutional and structural constraints which determined the level of ambition possible in its work. As Martin has argued: 'You can't make the sort of films we make within the mainstream tradition. That's fact' (Young 2001: 74). The development of institutional support for the regional workshop movement and the incorporation of their values, to a certain degree, within that support network enabled Amber to build and maintain a sophisticated, varied but also coherent exploration of regional identity and the nature of documentary representation. From the mid-1980s onwards this support has been in steady decline, supplanted by commercially oriented funding and commissioning policies which relegate issues of culture and identity to secondary or incidental importance. In this context, the vision of a regionally based, socially responsive cinema is well worth reiterating. In the words of Pat McCarthy:

We have always been driven by cultural rather than commercial concerns, and have never sought to be part of the mainstream of the industry. Our agenda has been concerned with establishing film as an 'art' form that has particular relevance to working-class people, and breaking through the cultural snobbery that sees film as somehow inferior to other art forms such as theatre, music, ballet and painting. We have campaigned for public funding of a filmmaking that is dedicated to the representation of regional cultures, and for the establishment of an alternative cultural film production, distribution and exhibition network; a national cinema that reflects and explores our national identity and regional filmmaking that reflects its diversities. (2002: 26)

While, as has been argued, Amber is an exemplar of workshop practice, it is also unique: the only regional film workshop to survive beyond the 1990s. As Graeme Rigby notes:

If you asked me to date, I think the Miners' Strike actually created the change. I think after the Miners' Strike the funding bodies stepped back from that kind of thing. At the time I personally don't think the Conservative government gave a toss about what was coming out of the arts-it was too small... But I think the arts were constantly keen to present themselves in a new way and that new way that was very much about making the case that they were economic; it was about supporting the national economy through culture and things like that. And that trend has continued and what we get now is that film presents what it is doing ... as generating a vibrant industry ... It is more that we no longer fit the structure that has become the necessary structure. We work in a different way. 


\section{Jack Newsinger}

As if to mirror this trajectory, Amber's films, when taken as a whole, chart a narrative of decline in the North East. If the 1970s was a period of the celebration of regional working-class identity, then in the 1980s this celebration becomes more complex and ambivalent, repeatedly returning to the themes of de-industrialisation and defeat. Shooting Magpies, released in 2007, might be said to represent the lowest point of this regional decline. Made on a shoestring, budget the film mixes documentary and reconstruction to chart a community dealing with the devastation wreaked by a generation of young people who have known only unemployment.

Amber's body of work is unique in British cinema through its coherent engagement with the North East over nearly four decades, and in this sense represents a theoretically informed attempt to continue in the footsteps of the British documentary movement first conceived by Grierson in the 1930s.

\section{Acknowledgements}

Special thanks are due to Graeme Rigby of the Amber Film Workshop for agreeing to be interviewed for this article. Thanks are also due to Tobias Hochscherf for generously providing me with his forthcoming chapter on Amber.

\section{Notes}

1. Amber's most significant campaigning work was centred on the independent media campaign in support of the Miners' Strike, part of wider involvement from the independent film sector. News From Durham and Where Are We Going (1983) was the first in a series of films made by Amber's 'current affairs unit' which covered the build up to and aftermath of the strike in different ways. Beyond the Vote (1984), for example, covered the Chesterfield by-election of March 1984 and shows a growing crossover between the politics of industrial action and the anti-nuclear and peace movements, explored in more detail in Can't Beat it Alone (1985). Both films were made for Channel 4's Eleventh Hour programme stream. Amber also worked on the widely celebrated Miners' Campaign Tapes, a project coordinated by the London-based workshop Platform Films to bring together material recorded by film workshops from across the country to counteract the mainstream media's hostility to the strike. The films won the prestigious John Grierson Award in 1985 and have recently been released on DVD by the British Film Institute. See Amber's catalogue, available at http://www.amber-online.co.uk (accessed November 2007).

2. Amber, and particularly Murray Martin, were active in the Association of Cinematograph, Television and Allied Technicians (ACTT) and the Independent Filmmakers' Association (IFA), and played a central role in negotiating the groundbreaking (but now defunct) Workshop Declaration, securing them revenue funding. For full details of this see Dickinson (1999: 46-74).

3. This has been tentatively advanced by Andrew Higson (1986: 96) and Ian Aitken (1998: 61).

4. It is now widely known, though perhaps not as widely as it should be, that the confrontation with the NUM was a key stage of the 'Ridley Plan', conceived before 


\section{The Interface of Documentary and Fiction}

Thatcher came to power, to take on and defeat the unions one by one, starting with the weaker ones and moving on to the strongest, thus breaking the workingclass power base and so paving the way for the radical economic restructuring of the British economy along 'free market' lines. The plan was leaked to the Economist (Anon. 1978) and in the context of the Miners' Strike is discussed in Beynon (1985) and Winterton (1989).

5. Aitken, for example, comments: 'Despite the populist rhetoric he often employed, Grierson's work and ideas were aimed, consciously or unconsciously, at the middle-class audience who read the minority journals and watched educational or "interest" films. This posed a contradiction which he was never able to adequately resolve... the documentary movement was primarily dedicated to the communication of ideas to governing elites and intellectuals' (1990: 173).

6. Interestingly, Rigby notes that with 'a film like Seacoal, one of the reasons for pushing it to drama is that a lot of the people working on Seacoal were working in the black economy. By fictionalising it you give them some protection'.

\section{References}

Aitken, I. (1990), Film and Reform: John Grierson and the Documentary Film Movement, London: Routledge.

Aitken, I. (1998), 'Introduction', in I. Aitken (ed.), The Documentary Film Movement: an Anthology, Edinburgh: Edinburgh University Press, pp. 1-68.

Amber (2005), A Short History, Newcastle: Amber.

Anon. (1978), 'Appomattox or civil war?', The Economist, 27 May, p. 21.

Beynon, H. (1985), Issues in the Miners' Strike, London: Verso.

Beynon, H. (2001), 'Documentary poet: Muray Martin', in S. Rowbotham and H. Beynon (eds), Looking at Class: Film, Television and the Working Class in Britain, London: Rivers Oram Press.

Byrne, D. (2001), 'The reconstruction of Newcastle: planning since 1945', in R. Colls and W. Lancaster (eds), Newcastle Upon Tyne: A Modern History, Chichester: Phillimore, pp. 341-60.

Colls, R. (2002), Identity of England, Oxford: Oxford University Press.

Colls, R. and Dodd, P. (1985), 'British documentary film, 1930-45', Screen 26: 1, pp. 21-33.

Dickinson, M. (1999), 'A short history', in M. Dickinson (ed.), Rogue Reels: Oppositional Film in Britain, 1945-90, London: BFI, pp. 17-86.

Fitzgerald, T. (1988), 'Shoptalk', Sight and Sound, Summer, pp. 163-9.

Grierson, J. (1998), 'Untitled Lecture on Documentary', in I. Aitken (ed.), The Documentary Film Movement: An Anthology, Edinburgh: Edinburgh University Press, pp. 76-7.

Harvey, S. (1981), 'Does cinema in Britain have a future?', Independent Cinema and Regional Film Culture, London: University of London Institute of Education.

Higson, A. (1986), “'Britain's outstanding contribution to the film”: the documentaryrealist tradition', in C. Barr (ed.), All Our Yesterdays: 90 Years of British Cinema, London: BFI, pp. 72-97.

Higson, A. (1995), Waving the Flag: Constructing a National Cinema in Britain, Oxford: Clarendon Press.

Hochscherf, T. and Leggott, J. (forthcoming), 'From Launch to Shooting Magpies: locating the Amber Film Collective', in H. Fawcett (ed.), Made in Newcastle: Visual Culture, Newcastle: Northumbria University Press. 


\section{Jack Newsinger}

McCarthy, P. (2002), 'A lasting light', Vertigo, 2: 3, pp. 26-7.

Newbury, D. (2002), 'Documentary practices and working-class culture: an interview with Murray Martin', Visual Studies, 17: 2, pp. 113-28.

Russell, D. (2004), Looking North, Manchester: Manchester University Press.

Sussex, E. (1972), 'Grierson on documentary: the last interview', Film Quarterly, 26: 1, pp. 24-30.

Taylor, R. (1995), 'Opportunities knocked? Regional broadcasters and grant-aided film production', Vertigo, 1: 5 , pp. 57-9.

Vall, N. (2001), 'The emergence of the post-industrial economy in Newcastle 1914-2000', in R. Colls and W. Lancaster (eds), Newcastle Upon Tyne: A Modern History, Chichester: Phillimore, pp. 47-71.

Weight, R. (2002), Patriots: National Identity in Britain 1940-2000, London: Macmillan. Winterton, R. (1989), Coal, Crisis and Conflict: The 1984-85 Miners' Strike in Yorkshire, Manchester: Manchester University Press.

Young, N. (2001), 'Forever Amber: an interview with Ellin Hare and Murray Martin of the Amber Film Collective', Critical Quarterly, 43: 4, pp. 61-74.

Jack Newsinger is a visiting lecturer at the University of the West of England. His research interests centre on postwar British film, focusing on policy and the politics of practice. His current research examines the development of regional film-making in England from the 1970s to the present. He has published in the Journal of Media Practice and Vertigo, and is a member of the editorial board of Scope: An Online Journal of Film Studies. 